\title{
Permit for exceptions to prohibitions introduced to protect species of plants, animals and fungi
}

\author{
Zezwolenie na odstępstwa \\ od zakazów wprowadzonych \\ w celu ochrony gatunkowej roślin, \\ zwierząt i grzybów
}

http://dx.doi.org/10.12775/PYEL.2014.007

Abstract

Prohibitions of taking certain actions against individuals of protected species established to protect the species are at the heart of this protection, guaranteeing its real dimension and meaning. However, these prohibitions

Doctor of Laws, Assistant Professor at the Environmental Law Protection Department of Nicolaus Copernicus University in Torun. 
are absolute in nature. The legislator allows for exceptions to prohibitions, introduced at the level of a generally applicable law, which create a system of legal protection of certain species of plants, animals and fungi. The basic mechanism of these exceptions is the permit, which is an individual administrative act issued at the request of the concerned entity. The permit repeals, in relation to a recipient specified by name, a generally applicable prohibition of certain activities and in this respect is an exception to the general rules.

Key words: Protection of nature; protection of species; permit for exceptions

\section{Streszczenie}

Ustanowione $\mathrm{w}$ celu ochrony gatunkowej zakazy podejmowania określonych czynności w odniesieniu do osobników gatunków objętych ochroną stanowią istotę tej ochrony, gwarantując jej rzeczywisty wymiar i sens. Zakazy te nie maja jednakże charakteru bezwzględnego. Ustawodawca dopuszcza bowiem odstępstwa od przyjętych, na poziomie przepisów powszechnie obowiązujących, zakazów tworzących systemu prawnej ochrony określonych gatunków roślin, zwierząt i grzybów. Podstawowym mechanizmem wprowadzenia tych odstępstw jest zezwolenie, stanowiące indywidualny akt administracyjny, wydawane na wniosek podmiotu zainteresowanego. Zezwolenie to uchyla, w stosunku do imiennie oznaczonego adresata, powszechnie obowiązujący zakaz podejmowania określonych czynności i w tym zakresie stanowi wyjątek od ogólnie przyjętych zasad.

Słowa kluczowe: Ochrona przyrody; ochrona gatunkowa; zezwolenie na odstępstwa

Protection of species of plants, animals and fungi along with conservation areas are two basic pillars of the legal protection of nature. The essence of this protection is to establish, at the level of a generally applicable law, prohibitions relating to the enumerated protected species of plants, animals and fungi. The prohibitions are not absolute. The legislature allows for exemptions from them, introduced by either an individual administrative act - permit, or by the general act. The subject of this paper is to discuss the substantive and procedural conditions of the permit for exceptions introduced to protect species of plants, animals and fungi, which is an individual administrative act. 
In Poland the basic act concerning the protection of species of plants, animals and fungi is the Act on Nature Protection of 16 April 20041. In terms of the species protection, this act implemented the Directive on the conservation of natural habitats and of wild fauna and flora ${ }^{2}$ and the Directive on the conservation of wild birds ${ }^{3}$. According to the assumptions of the legislator, nature conservation consists of preservation, sustainable use and restoration of resources, objects and wildlife components, in order to maintain ecological processes, ecosystem stability, biodiversity conservation, as well as the preservation of geological and paleontological heritage. Another aspect is, to ensure the continuity of species of plants, animals and fungi along with their habitats, through their maintenance or restoration to appropriate protection level, protection of landscape values, green areas in towns and villages and forested areas, as well as to maintain or restore the appropriate protection level of natural habitats and other resources, objects and components of nature, and to create appropriate human attitudes towards nature through education, information and promotion in the field of nature conservation. These aims are performed inter alia by taking resources, objects and wildlife components into protection through forms of nature protection, in which the legislature includes, in accordance with article 6 point 10 of u.o.p., protection of species of plants, animals and fungi. In accordance with article 46 of u.o.p., protection of species is meant as protection of: specimens of species and habitats and refuges of plants, animals and fungi. Its aim is to ensure the survival and appropriate protection level of species of wild plants, animals and fungi which are rare, endemic, vulnerable and endangered in their natural environment, but protected, on the basis of the provisions of international agreements to which the Republic of Poland is a party. Another, but equally important aim is the protection of the habitats and refuges in the country or other European Union Member States, and the preservation of species and genetic diversity. The concept of species protection is performed through

\footnotetext{
1 Journal of Laws of 2013, item 627 with amendments; hereinafter referred to as the Act on Nature Protection or u.o.p.

2 The Council Directive 92/43/EEC of 21 May 1992 on the conservation of natural habitats and of wild fauna and flora, OJ L 206, 22.07.1992, p. 7-50.

3 The Council Directive 79/409/EEC of 2 April 1979 on the conservation of wild birds, OJ L 103, 25.04.1979, p. 1-18 repealed by the Directive 20009/147/EC of the European Parliament and of the Council of 30 November 2009 on the conservation of wild birds, OJ L 20, 26.1.2010, p. 7-25.
} 
the determination by the minister competent for the environment, in consultation with the minister competent for the agriculture, lists of species of plants ${ }^{4}$, animals ${ }^{5}$ and fungi $\left.{ }^{6}: 1\right)$ under strict protection, specifying the species in need of active protection, 2) under partial protection, 3) under the partial protection which can be collected, and ways of collecting and 4) requiring the creation of protected refuge zones or positions, in the case of plants and fungi, and protected refuge zones, breeding sites or regular residence in the case of animals, and determining appropriate prohibitions and exceptions to these prohibitions for different groups and species. A register of acceptable prohibitions has been formulated at the level of an act in relation to protected species of plants and fungi in article 51 section 1 and 1a of u.o.p. and in article 52 section 1 and 1a of u.o.p. in relation to the protected animals. In the case of the abovementioned life forms, the legislature diversified a range of acceptable prohibitions in relation to wild plant, animal and fungus species, and other than wild plant, animal and fungus species under protection. This distinction was introduced into the Polish legal regulations by the amendment to the Act on Nature Protection, which came into force on 1 October $2012^{7}$. In accordance with article 5 point $15 \mathrm{a}$ u.o.p. the definition of wild plant, animal or fungus should be understood as plant, animal or fungus that does not derive from cultivation or farming, or is not introduced into the natural environment in order to rebuild or supply the population. In relation to wild plants and fungi species under the species protection, the minister competent for the environment may introduce prohibitions of: 1) deliberate destruction, 2) deliberate picking or damaging, 3) destruction of their habitat or refuges, 4) making changes to water system, using chemicals, destruction of forest litter and destruction of soil in refuges, 5) culture, 6) collecting or harvest, 7) keeping or possession of specimens of species, 8) selling, offering for sale, exchange, donation or transport of specimens of species, 9) bring in from abroad or exporting outside the state specimens of species, 10) deliberate

4 Regulation of the Minister of the Environment of 5 January 2012 on plants species protection, Journal of Laws of 2012, item 81.

5 Regulation of the Minister of the Environment of 12 October 2011 on animals species protection, Journal of Laws of 2011, No 237, item 1419.

6 Regulation of the Minister of the Environment of 9 July 2004 concerning species of wild fungi under protection, Journal of Laws of 2004, No 198, item 1765.

7 The Act of 13 July 2012 on the amendment of the Act on Nature Protection and some other acts, Journal of Laws of 2012, item 985. 
interference in the natural environment, and 11) deliberate introduction into the natural environment. Whereas, in the case of other than wild plants and fungi under the species protection these prohibitions may relate to: 1) culture, 2) keeping or possession of specimens of species, 3) selling, offering for sale, exchange, donation or transport of specimens of species, 4) bring in from abroad or exporting outside the state specimens of species, and 5) deliberate introduction into the natural environment. In the case of wild animals under species protection the catalogue of permissible restrictions include a prohibition of: 1) deliberate killing, 2) deliberate mutilation or capture, 3) deliberate destruction of their eggs, juvenile forms or forms of development, 4) transport, 5) farming and breeding, 6) collecting, capture, keeping, possession, or preparation of specimens of species, 7) destruction of habitats and refuges that are their area of breeding, rearing, resting, migration or feeding, 8) destruction, removal or damage of nests, anthills, burrows, dens, lodges, dams, spawnings, places of wintering or other shelters, 9) deliberate providing against an access to shelters, 10) selling, offering for sale, exchange, donation or transport for sale of specimens of species, 11) bring in from abroad or exporting outside the state specimens of species 12) deliberate startling or disturbance, 13) deliberate startling or disturbance in the places of accommodation, during the breeding season in the breeding places or in the places of prey of floks migrating or wintering birds, 14) shooting, filming or observing, which may cause them startling or disturbance, 15) deliberate movements of the sites resided regularly into other places, and 16) deliberate introduction into the natural environment. In relation to other than wild animals of protected species following prohibitions can be introduced: 1) deliberate killing, 2) deliberate destruction of their eggs, juvenile forms or forms of development, 3) transport, 4) farming and breeding, 5) capture, possession or preparation of specimens of species, 6) selling, offering for sale, exchange, donation or transport for sale of specimens of species, 7) bring in from abroad or exporting outside the state specimens of species, and 8) deliberate introduction into the natural environment.

At the stage of inclusion of a given species into the species protection the minister competent for the environment may introduce exceptions to the established prohibitions if they are not detrimental to the maintenance at the appropriate status of conservation of wild populations of protected species and there are no alternatives. In the case of plants and fungi the possible exceptions concern: 1 ) perform the duties related to the conduct 
of rational agriculture, forestry or fishing, if the technology of works makes it impossible to comply with the prohibitions, 2) removing of plants and fungi which destroy materials or building structures, 3) collecting species under partial protection, which can be collected by operators who have obtained a permit for their collecting from the regional director for environmental protection or the General Director for Environmental Protection, 4) keeping, possession, selling, offering for sale, exchange, donation, as well as exporting outside the state of specimens of species under partial protection which can be collected on the basis of the permit referred to in point 3,5 ) keeping, possession, selling, offering for sale, exchange, donation, as well as exporting outside the state of specimens of species under partial protection collected outside the country and brought in from abroad on the basis of the permit from the regional director for environmental protection or the General Director for Environmental Protection. Exception to prohibition of deliberate destruction, does not apply to the species listed in Annex IV of the Council Directive 92/43/EEC on the conservation of natural habitats and of wild fauna and flora. In relation to the species under the species protection the legislator allows for derogations concerning: 1) removal, during the period from 16 October to the end of February nests from the boxes for birds and mammals, 2) removal, during the period from from 16 October to the end of February nests of birds from buildings or landscape, if it is necessary for safety or health, 3) capture stray animals in urban areas by persons authorized by the regional director for environmental protection and moving them to the places of regular occurrence, 4) capture injured or weakened animals in order to give them veterinary help and moving them to the centers of animal rehabilitation, 5) prevention from serious damage to crops, livestock, forests, fish stocks, water, or other types of property ${ }^{8}$, 6) collecting specimens under partial protection which can be collected by operators who have obtained a permit for their collecting from the regional director for environmental protection or the General Director for Environmental Protection, 7) keeping, possession, selling, offering for sale, exchange, donation, as well as exporting outside the state specimens of species under partial protection which can be collected on the basis of the permit referred to in point 6,8$)$ keeping, possession, selling, offering for sale, exchange, donation, as well as exporting outside the state specimens

8 In the case of birds prevention from serious damage refers to crops, livestock, forests, fish stock or water. 
of species collected outside the country and brought in from abroad on the basis of the permit from the regional director for environmental protection or the General Director for Environmental Protection, 9) collecting and storage of bird feathers.

Both the determination of the protected species of plants, animals and fungi, and introducing appropriate prohibitions and exceptions to these prohibitions, by the regulation of the minister competent for the environment, is of general application. Legal regulation in this case is made by means of abstract and general rules which apply to unspecified circle of addressees (everyone - all) and repetitive behaviors. This means that the rules stipulated in this regulation bind everyone and include all the situations corresponding to the hypothesis of those standards.

From such a specific legal regulation the legislator allows for exception in the form of the authority of public administration authorities to repeal, by an individual administrative act, certain prohibitions resulting from the protection of species. This repeal is made at the request of the entity only if certain statutory prerequisites occur and it takes a form of an administrative permit. The doctrine of the administrative law suggests that the administrative permit is an institution of substantive administrative law. It involves undertaking actions by executive administration authorities to enable the entity to manifest certain behavior, which without the permit would not be legally permitted (prohibited) ${ }^{9}$.

According to article 56 section 1 and 2 of u.o.p. the General Director for Environmental Protection (article 56 section 1 of u.o.p.) or the regional director for environmental protection (article 56 section 2 of u.o.p.) may allow, in relation to the protected species, to undertake the activities which come under the prohibitions set out in article 51 section 1 and 1a of u.o.p. and article 52 section 1 and 1a of u.o.p. The division of powers between the environmental authorities has been made basing on the type of the repealed prohibition, the character of the established protection (strict, partial) and the territorial coverage of the permit. The competence of the General Director for Environmental Protection is to issue permits: 1) to bring in from abroad or export outside the state specimens of species under strict protection, 2) to deliberately kill specimen of species under strict protection, 3) to deliberately introduce into the environment specimens

9 D.R. Kijowski, in: System prawa administracyjnego, vol. 7, Prawo administracyjne materialne, ed. R. Hauser, Z. Niewiadomski, A. Wróbel, Warszawa 2012, p. 384. 
of animals' species under strict protection, 4) to deliberately destruct eggs, juvenile form or forms of development of wild animals of the species under strict protection, and 5) concerning the area extending the boundaries of two voivodeships, or if it has to do with the actions taken by the minister competent for the environment, including implementation of a program of conservation and sustainable use of biological diversity, conservation programs of endangered species or international agreements. In other cases, the permit to undertake actions covered by the prohibitions set out in article 51 section 1 and $1 \mathrm{a}$ of u.o.p. and article 52 section 1 and $1 \mathrm{a}$ of u.o.p. is issued by the regional director for environmental protection. The exception to the abovementioned division of competences are areas of the national parks, in respect of which the permit to undertake the prohibited actions is issued by the minister competent for the environment, after consultation with the director of the park.

The permit for exceptions to prohibitions introduced to protect species of plants, animals and fungi may be issued only if three prerequisites are met: 1) there is no alternative, 2) exceptions are not detrimental to the maintenance at the appropriate status of conservation of wild populations of the protected species of plants, animals or fungi 3) there is at least one of the circumstances enumerated in article 56 section 4 of u.o.p. In those circumstances the legislature includes: 1) actions which are exceptions to prohibitions that are in the interest of protection of wild species of plants, animals, fungi or conservation of natural habitats, or 2) these actions result from the need to reduce serious damage to crops, livestock, forests, fish stocks, water, or other types of property ${ }^{10}$, or 3) these actions are in the interest of public health or safety, or 4) are necessary for the implementation of research, educational activities or purposes of repopulating, reintroduction of species of plants, animals or fungi, or for the purpose of breeding operations, including the artificial propagation of plants, or 5) allow, under strictly supervised conditions, at a selective and limited level, collecting or keeping specimens of plants and fungi, and capturing, collecting or keeping specimens of protected species of animals in the number specified the by the entity issuing the permit, or 6) in the case of species under strict protection, species of birds and other species listed in Annex IV of the Council Directive 92/43/EEC of 21 May 1992

10 In the case of bird species this condition relates to damage to crops, livestock, forests, fish stock or water. 
on the conservation of natural habitats and of wild fauna and flora - actions which result from necessary requirements of overriding public interest, including the social or economic requirements or requirements relating to the beneficial effects of primary importance for the environment ${ }^{11}$, or 7) in the case of species other than those listed in point 6 - actions which result from the legitimate interests of the parties or the necessary requirements of overriding public interest including the social or economic requirements or requirements relating to the beneficial effects of primary importance for the environment.

In the case of permits for activities subjected to prohibitions of: 1) bringing in from abroad or exporting outside the state specimens of protected species of plants, animals and fungi, and 2) deliberate startling or disturbance in the places of accommodation, during the breeding season in the breeding places or the places of rearing of the young or in the places of preying by the flock of migrating or wintering birds, protected birds species, the prerequisite to issue the permit is the lack of alternatives and the finding that these activities are not detrimental to the maintenance at the appropriate status of conservation of wild populations of the protected species.

The permit for the collection of species of plants, animals and fungi under the partial protection that can be collected, may be issued if the activities covered by the permit are not detrimental to the maintenance at appropriate status of conservation of wild populations of protected species.

The permit for banned activities which result from the protection of species of plants, animals and fungi is an administrative decision which is issued under the provisions of the Code of Administrative Proceedings ${ }^{12}$. This decision is issued on request. The application must contain, respectively: 1) name, surname and abode or name and address of the applicant, 2) the purpose of proposed activities, 3) description of actions, which may be permitted, 4) name of species, which will be affected by activities, in Latin and Polish, if Polish name exists 5) number or amount of individuals concerned, if it is possible to determine 6) indicating methods and equipment used to capture, catch or kill animals or method of collection

11 This condition, in the case of bird species applies only to issuing the permit for the destruction of habitats and refuges that are the area of breeding, rearing, resting, migration or feeding.

12 The Act of 14 June 2012 The Code of Administrative Proceedings with amendments, Journal of Laws of 2013, item 267; hereinafter referred to as k.p.a. 
of plants and fungi, or methods of performing other actions which may be permitted, as well as place and time of performance of activities, and the anticipated risks, 7) indication of entity who will catch or kill animals. If the content of the request does not qualify for a statutory requirements, the authority conducting the proceedings calls the applicant to complete the application within the statutory period of 7 days. Failing to complete of the application within this period will leave it without a hearing. In the situation where the application is complete, the authority should take a decision immediately, no later than within 1 month, in particularly complex cases, no later than within 2 months.

An important matter, from the point of view of procedural guarantees to ensure the participation of the parties in the proceedings, is the correct determination of the group of people whose rights and obligations will be decided by a public authority. According to the general rule expressed in article 28 of k.p.a, a party to the proceedings is anyone whose legal interest or obligation this proceedings applies to or who requests an action of the authority, due to his or her own legal interest or duty. It is obvious that a party to proceedings for permit to undertake activities covered by the prohibitions resulting from the protection of the species is the applicant. But the question is whether the status of the parties also is granted to other entities e.g. the owner of the forest (who is not the applicant) where actions for which the permit is given may be taken. I think that this question should be answered in the positive way. The permit for exceptions to prohibitions does not rule on the right to use the property by the applicant but determines to some extent (subject to rationing) the rules of using it. Thus constituting interference with the right of ownership, which in turn justifies the grant of the status of the party of the administrative decision to the land owner ${ }^{13}$.

The permit for exceptions to prohibitions introduced to protect species is a discretionary decision because the legislature used a phrase the authority "may permit". In the doctrine of the administrative law it is assumed that the administrative discretion is a normative structure consisting of granting to the public authorities the possibility to choose between two or more permissible by law, and legally equal, solutions ${ }^{14}$. As E. Ochendowski notes, discretion occurs when a rule does not determine unambiguously

13 See: Judgement of the Voivodeship Administrative Court in Warszawa of 25 February 2014, IV SA/Wa 2134/13, source: www.orzeczenia.nsa.gov.pl.

14 See: J. Zimmermann, Prawo administracyjne, Warszawa 2012, p. 318. 
legal effect but clearly leaves the way to make such a choice, from the effects specified in the act, for public authorities ${ }^{15}$. However this choice cannot be arbitrary. In the opinion of the Constitutional Court, "in accordance with the requirements of the rule of law (...) there cannot be any hypothetical $<$ free > actions of the administration, i.e., which within certain limits are outside the law and are uncontrolled. The discretion is transformed from the formal institution, which establishes free, not bound by anything opportunity to decide, into only a more flexible form of administration that allows and obliges the authorities to investigate all the circumstances of the case in order to find the most appropriate settlement, corresponding to the objective truth and its goal. Thus, the discretion is thus a particular form of implementation of the law which consists in the fact that the authority applying law has to take into account the individual circumstances of each case, the statement of which is possible only at the stage that the decision might be issued in accordance with the will of the legislature. However, the action of the authority must be reasonable and shall be a subject to inspection" ${ }^{\prime 16}$. This means that in the aspect of considering the administrative case of the permit for exceptions to prohibitions introduced to protect species, despite the existence of the prerequisites enumerated in article 56 of u.o.p., the authority is not bound by the absolute obligation to issue a positive decision ${ }^{17}$. Fulfillment of statutory prerequisites is fundamental for the public authority for administrative discretion based on the possibility to choose the consequences of the legal norm, i.e. a positive or negative resolution for the applicant. This choice, of course, cannot be due to any unlimited and unverified beliefs of the administrative authority. It is primarily based on the balance of the public interest and the interests of the individual applicant and the directives from the rules of the administrative procedure taking into account the legitimate interests of the parties and the principle of citizens' trust in the public administration. If it is determined, during the administrative procedure, that there are no prerequisites to issue

15 E. Ochendowski, Prawo administracyjne. Częśc ogólna, Torun 2009, p. 210.

16 Judgement of the Constitutional Court of 29 September 1993, K 17/92, OTK of 1993, No. 2, item 33.

17 In the doctrine of the environmental law the opposite view has been expressed. In the opinion of W. Radecki, in the case of occurrence of all the conditions of the permit, the applicant has a claim to the administrative authority for issuing the permit. W. Radecki, Ustawa o ochronie przyrody. Komentarz, Warszawa 2008, p. 194-195. 
the permit for exceptions, the administrative authority refuses to issue it and this decision is binding (it is not a discretionary decision).

The permit for exceptions to prohibitions introduced to protect species, as a classical administrative decision must correspond to the general formal requirements set out in article 107 of k.p.a., and therefore, indicates the authority issuing the decision, the date of the settlement, defines the parties to the decision, the legal basis, the settlement, factual and legal grounds, instruction on available legal remedies, and contains a signature of the person issuing the decision with stating the official position. In addition to the specified elements the legislature obliges the authority to conclude specific provisions in the decision which are contained in the catalogue in article 56 section 7 of u.o.p. Under this provision the permit for exceptions to prohibitions contains accordingly: 1) name, surname and abode or name and address of the applicant, 2) name of species, which will be affected by activities, in Latin and Polish, if Polish name exists, 3) number or amount of individuals concerned, if it is possible to determine, 4) description of activities for which the permit is issued, 5) indication of methods and equipment used to capture, catch or kill animals or method of collecting plants and fungi or methods of performing other actions, which may be permitted, 6) determine time and place of actions which are permitted, 7) indication of entity who will catch or kill animals, 8) determined deadline for submission of information on the use of the permit, 9) conditions resulting from the implementation of the need to protect the population of the protected species of plants, animals and fungi and their habitats. The analysis of these provisions gives the impression that they, except for the data concerning the applicant, detail the settlement which is a mandatory component of any administrative decision. This means that in case of missing in the permit any of the elements stipulated in points $2-9$, the institution of completion the administrative decision (stated in article 111 of k.p.a.) will have to take place. Under this provision, both at the request of the party and ex officio, the authority who issued a decision can complement it as to the settlement. But the deadline for submission of the application to supplement and the deadline for completion ex officio is 14 days from the date of the decision notification to the party. An appeal against the decision issued in the first instance by the regional director for environmental protection is possible, within 14 days, and is addressed to the General Director for Environmental Protection. Whereas in the case of a decision issued in the first instance by the General 
Director for Environmental Protection and by the minister competent for the environment, the party who is dissatisfied with the decision may within 14 days submit a request for review by the same authority. This is due to the fact that both the General Director for Environmental Protection and the minister are the central authorities, which means that, according to article 127 paragraph 3 of k.p.a., there is no appeal against the decisions issued by them but a request for a review is possible.

An important element of the system of the protection of species of plants, animals and fungi, is an effective control of the correctness of use of the permit for exceptions to prohibitions connected with the protection of individual species. Control authorities in this sphere are the authorities who issue the permits. The subject of control is meeting the conditions set out in the permit issued by the public authorities. The analysis of article 56 section 7 of u.o.p., which refers to the mandatory elements of the permit, may create some doubts whether the scope of the control covers only the conditions for the implementation of the permit concerning the needs to protect the populations of the protected species of plants, animals and fungi and their habitats, or all the relevant elements of the settlement indicated in article 56 section 7 points $2-8$ of u.o.p. It must be indicated that there is a wide range of objects of control covering all elements of the permit, such as e.g.: species affected by the action, number or amount of individuals concerned, actions which may be permitted, including methods and equipment used to capture, catch or kill animals, or method of collecting plants and fungi or methods of performing other actions, time and place of performance of activities, entities who catch or kill animals, determine the date of providing information about the implementation of the permit and conditions for the implementation of the permit resulting from the need to protect the population of the protected species of plants, animals and fungi and their habitats. Controls are carried out by persons having registered authorization issued by the authorities competent to issue permits, which defines the person authorized to perform the control, location and the extent of the control and the legal basis for its performance. Persons authorized to perform the control have the right to: 1 ) enter the premises owned by a controlled entity, but entering and carrying out the control may be performed only in the presence of the owner or holder of the property, 2) demand written or oral information related to the subject of control, and 3) access the documents relevant to the control, prepare copies, extracts or duplicates of those documents, and secure those documents. 
The consequence of finding by the authority, who issued the permit, that the holder does not meet the conditions contained in it, is withdrawal of the permit. In this case, the withdrawal of the permit has a mandatory nature, as evidenced by the phrase "the permit...is withdrawn", and it is the administrative sanction. The literature suggests that the possibility of the withdrawal or restriction of the right is a way of responding to the problems of public administration, which may occur in the phase of its implementation by the entity ${ }^{18}$. The retributive nature of the withdrawal of the permit, in the case of the application of this institution, is proved by the fact that it contains all the characteristics of a sanction, such as statutory legal grounds, the consequence of the unlawful conduct by the entity, preventive and repressive nature, imperious action of the administrative authority, taking into account the principle of proportionality ${ }^{19}$. Bearing in mind the imperious activity of the authority and causing the direct legal effect, it must be assumed that the withdrawal of the permit shall be followed by issuance of an administrative decision, after the initiation of administrative proceedings ex officio. In the case of issuing the administrative decision, the legal effect of the withdrawal of the permit will be the date on which the decision concerning withdrawal becomes final. Therefore, the authority issuing this decision, taking into account the gravity of the violations in the implementation of the permit for exceptions to prohibitions, should consider the possibility of giving the withdrawal decision an immediate enforceability. In accordance with article 108 of k.p.a., this rigour is imposed e.g. because of the public interest. Imposing the withdrawal decision an immediate enforceability causes the situation where the rights granted by the permit cease on the date of delivery of the withdrawal decision.

Separate, from the permit for exceptions to prohibitions introduced in order to protect the species, source of exemption from the obligation to respect these prohibitions are exemptions from the prohibitions confirmed by an appropriate certificate or permit issued on the basis of the Council Regulation (EC ) No 338/97 of 9 December 1996 on the protection

18 K. Frączak, Cofnięcie bądź ograniczenie uprawnienia jako sankcja administracyjna, in: Sankcje administracyjne, eds. by M. Stahl. R. Lewicka, M. Lewicki, Warszawa 2011, p. 109.

19 See: Z. Duniewska, Sankcja administracyjna, in: Z. Duniewska, B. Jaworska-Dębska, R. Michalska-Badziak, E. Olejniczak-Szałowska, M. Stahl, Prawo administracyjne, Pojęcia, instytucje, zasady w teorii i orzecznictwie, Warszawa 2002, p. 66. 
of species of wild fauna and flora by regulating trade therein ${ }^{20}$. Those exemptions deal with specimens of species for which they were issued, as the exemption equivalent to the permit issued according to article 56 section 1,2 and 2b of u.o.p., if applicable prohibition of: 1) keeping dead specimens of species, 2) possession, donation, transport, bringing in or exporting trough intra-community border and actions that have been released in this permit relative to specimens of the species.

A kind of substitute for the permit for exceptions to prohibitions introduced to protect species is the decision on the conditions of performing activities mentioned in article 118 section 1 of u.o.p. Under this provision, performing activities mentioned in article 22 section $1 b^{21}$ of the Water Law ${ }^{22}$, water drainage, extraction of stone, gravel, sand and other materials from water, within the specific use of water, and other than those mentioned above activities involving earth works that may change the water or water and soil relations, need to be notified to the regional director for environmental protection, if it is performed in conservation areas, mentioned in article 6 section 1 point $1-5$ and 7-9 of u.o.p. in protective spheres introduced by the Inland Fisheries Act ${ }^{23}$, as well as within the natural watercourses. Those works can be carried out after 30 days from the date of notification, unless the regional director for environmental protection raises objection in the form of a decision within this period. In the decision, the regional director for environmental protection may impose an obligation to obtain a decision on the conditions

20 OJ L 61, 3.3.1997, p. 1 with amendments.

21 In accordance with article 22 section $1 \mathrm{~b}$ of Water Law: "Keeping the water is performed by: 1) mowing plants from the bottom and edges of the inland surface waters, 2) removal of floating plants and rooting plants in the bottom of inland surface waters, 3 ) removal of trees and shrubs growing on the bottom and on the edges of inland surface waters 4) removal natural barriers and barriers resulting from human activities from inland surface waters, 5) swamp rifts in the edges and bottom of inland surface waters and by their biological development, 6) clear inland surface waters by removing obstructions hindering the free flow of water and removal of silt and rubble, 7) repair or maintenance owned by the owner of the water: a. regulatory structures and insurances within those structures, b. of water facilities, 8) demolition or modification of beaver's dams and burying beaver's burrows in the banks of inland surface waters".

22 The Act of 18 July 2001 on Water Law, Journal of Laws of 2012, item 145 with amendments.

23 The Act of 18 April 1985 on Inland Fisheries Act, Journal of Laws of 2009, No 189, item 1471 with amendments. 
of action if their conduct may: 1) violate regulations concerning the forms of nature conservation, mentioned in article 6 section 1 point $1-5$ and 7-9 of u.o.p., or in protective spheres introduced by the Inland Fisheries Act, 2) cause the deterioration of the environment, and in particular, can have a significant and negative effect on the conservation objectives of protected areas, violate prohibitions binding to them, or have a significant and negative effect on the habitats, protected species of plants, animals or fungi, or their habitat. If determining the terms and conditions of work constitutes an interference with prohibitions relating to the protection of species established by a generally applicable law, the issuing authority shall apply regulations of article 56 section 4-5 and 7-8 of u.o.p.. The decision which is issued replaces the permit for exceptions to prohibitions.

Prohibitions of taking certain actions against individuals of protected species established to protect the species are at the heart of this protection, guaranteeing its real dimension and meaning. However, these prohibitions are not absolute in nature. The legislator allows for exceptions to prohibitions, introduced at the level of a generally applicable law, which create a system of legal protection of certain species of plants, animals and fungi. The basic mechanism of these exceptions is the permit, which is an individual administrative act issued at the request of the concerned entity. The permit repeals, in relation to a recipient specified by name, a generally applicable prohibition of certain activities and in this respect is an exception to the general rules. The mechanism of the administrative decision gives public authorities the opportunity to assess the legal situation of a individually designated entity in the particular case, which is reflected in the content of the decision. And the construction of administrative discretion is an authorization to form the outcome of the case not only in terms of a fulfillment of the conditions stipulated in article 56 of u.o.p., but also according to the evaluation criteria such as the desirability of taking the settlement, its compliance with the principles of the environmental law, or balancing the public and the individual interest. A regular application of national rules in the field of nature conservation requires consideration of pro-community directive of interpretation of these provisions. As rightly pointed out by the Supreme Administrative Court "it means the obligation to interpret national legislation in a way to ensure the effectiveness of the community law and to allow proper functioning of the multicentric legal system, 
assuming the coexistence of regulations derived from the EU and national centers" 24 .

\section{Bibliography}

Duniewska Z., Sankcja administracyjna, in: Z. Duniewska, B. Jaworska-Dębska, R. Michalska-Badziak, E. Olejniczak-Szałowska, M. Stahl, Prawo administracyjne, Pojęcia, instytucje, zasady w teorii i orzecznictwie, Warszawa 2002.

Frączak K., Cofnięcie bądź ograniczenie uprawnienia jako sankcja administracyjna, in: Sankcje administracyjne, eds. by M. Stahl. R. Lewicka, M. Lewicki, Warszawa 2011.

Kijowski D.R., in: System prawa administracyjnego, vol. 7, Prawo administracyjne materialne, ed. R. Hauser, Z. Niewiadomski, A. Wróbel, Warszawa 2012.

Ochendowski E., Prawo administracyjne. Część ogólna, Toruń 2009.

Radecki R., Ustawa o ochronie przyrody. Komentarz, Warszawa 2008.

Zimmermann J., Prawo administracyjne, Warszawa 2012.

\section{Email}

szalewska@wp.pl

${ }^{24}$ Judgement of the Supreme Administrative Court of 12 February 2010, II OSK 1167/08, source: www.orzeczenia.nsa.gov.pl. 